\title{
DIET OF TADPOLES FROM A POND IN IGUAZU NATIONAL PARK, ARGENTINA
}

\author{
DIETA DE LARVAS DE ANUROS EN UNA LAGUNA DEL \\ PARQUE NACIONAL EN IGUAZU, ARGENTINA
}

\author{
Dinorah D. Echeverría ${ }^{1}$, Alejandra V. Volpedo ${ }^{1} \&$ Virginia I. Mascitti ${ }^{1}$ \\ ${ }^{1}$ Laboratorio de Vertebrados. Departamento de Biodiversidad y Biología Experimental. \\ Facultad de Ciencias Exactas y Naturales. Universidad de Buenos Aires. \\ C1428EHA. Buenos Aires. Argentina. E-mail: echeverria@bg.fcen.uba.ar
}

\begin{abstract}
Gut contents of anuran larva (Elachistocleis bicolor, Chaunus schneideri, Odontophrynus americanus, Scinax fuscovarius, and $S$. granulatus) that coexist in a semi-permanent waterbody from Iguazú National Park (Misiones, Argentina) was analyzed. Our objective was analyse the gut contents of different tadpole species that coexist in the same water body during seasons of minimum and maximum precipitation, to increase the knowledge of the natural history of these tadpoles. Elachistocleis bicolor (obligate-suspension-feeder) it presents only planktonic algae in its gut (92\%). In gut of S. fuscovarius and S. granulatus (nektonic) planktonic algae were abundant, especially in the rainy season (14 and $41 \%)$. The guts of $C$. schneideri and $O$. americanus (benthic) showed sediments $(55 \%$ and $17.5 \%)$ and vegetable fibers (33 and $61 \%)$. The largest particle size $(\leq 100 \mu \mathrm{m})$ was found in the guts of C. schneideri and the smallest $(\leq 25 \mu \mathrm{m})$ in $O$. americanus and E. bicolor.
\end{abstract}

Keywords: Anura, tadpoles, feeding, diet, Iguazú National Park.

\section{RESUMEN}

Se analizó el contenido intestinal de larvas de anuros (Elachistocleis bicolor, Chaunus schneideri, Odontophrynus americanus, Scinax fuscovarius, y $S$. granulatus) que conviven en un cuerpo de agua semipermanente del Parque Nacional Iguazú (Misiones, Argentina). Nuestro objetivo fue analizar el contenido intestinal de diferentes especies de larvas que conviven en el mismo cuerpo de agua durante las estaciones de máxima y mínima precipitación pluvial, para incrementar el conocimiento de la historia natural de estas larvas. Elachistocleis (suspensívoros-obligado) presentó solamente algas planctónicas (92\%) en sus intestinos. Los intestinos de S. fuscovarius, y S. granulatus (nectónicas) presentaron principalmente algas planctónicas, especialmente en la estación de lluvia (14 y 41\%). Los intestinos de Chaunus schneideri y O. americanus (bentónicas) mostraron sedimentos (55 y $17.5 \%$ ) y fibras vegetales (33 y $61 \%)$. El mayor tamaño de partícula $(\leq 100 \mu \mathrm{m})$ se encontró en los intestinos de $C$. schneideri, y el más pequeño $(\leq 25 \mu \mathrm{m})$ en $O$. americanus y E. bicolor.

Palabras claves: Anura, renacuajos, alimentación, dieta, Parque Nacional Iguazú. 
Diet of tadpoles of Iguazú National Park: ECHEVERRía, D. ET AL.

\section{INTRODUCTION}

For several decades, the diet of exotrophic anuran larvae was examined in the context of freshwater phytoplankton communities (Farlowe 1928, Savage 1952, Costa \& Bramamian 1965). Heyer (1973) and Inger (1986) examined the gut contents of tadpoles from Thailand and Borneo rainforests, respectively, to associate diet with microhabitat and recognized different modes of feeding. Heyer (1976) found temporal distribution patterns of larvae species occurrence in several ponds of Thailand. In Argentina, studies on tadpole diet are scarce (Lajmanovich 1994, Lajmanovich \& Faivovich 1998). Feeding particles have been reported by Viertel $(1990,1992)$ in brief reports of suspension feeder tadpoles at low concentration of particles. Altig \& Johnston (1989) summarized most of the information concerning feeding modes, microhabitat use, and tadpole behaviour. In a waterbody, tadpoles use a wide range of microhabitats for feeding and exhibit different morphological characteristics and behaviours.

Hoff et al. (1999) assumed that tadpoles in general, should be considered opportunistic omnivores or detritivores. Different items reported from the intestines of tadpoles include detritus, sediments, animal and vegetable components (Sanderson \& Kupferberg 1999). Among the latter, periphyton is the most frequently reported item (Dickman 1968, Kupferberg et al. 1994). Studies of gut contents sometimes indicate interespecific and site differences in diet of anuran larvae (Heyer 1976, Waringer-Loschenkohl 1988, Skelly 1995). Attached algae and diatoms are important tadpole food items (Sanderson \& Kupferberg 1999). Observations of diatoms in tadpole feces (Kupferberg et al. 1994) showed that many cells passed through the gut with frustules intact, but with cell contents gone. Echeverría \& Conforti (2000) found euglenoids living in the intestine of E. bicolor tadpoles, and concluded that euglenoids are not part of larvae diet. Some larvae feed on attached algae and have displayed the ability to distinguish and differentially consume high quality taxa that are rich in proteins and lipids (Kupferberg 1997a).

The increase in abundance and diversity of phytoplankton in a pond is related to the rapid growth of algae during spring and to climatic conditions (Izaguirre et al. 1986). Exogenous food effects supplies on growth and development have been interpreted mainly from and ecological perspective (Sanderson \& Kupferberg 1999) within several subjects (i.e.: predation, competition, phenotypic plasticity (Werner 1986, Smith \& Van Buskirk 1995, Kupferberg 1997 a,b,c).

The abundance of tadpoles in lenthic waterbodies is associated with the reproductive cycles of adult anurans (Heyer 1973). Gallardo \& Varela de Olmedo (1992) documented reproductive period of the anurans in Northeastern Argentina and found that it extends from early spring (September) to late summer (March). Northeast Argentina is rich in lenthic waterbodies where several species of anuran tadpoles usually coexist in the same season (Cei 1980).

The aim this study was to analyse the gut contents of different tadpole species that co-occurred in the same water body during seasons of minimum and maximum precipitation, to increase our knowledge on their natural history.

\section{MATERIALS AND METHODS}

The study area is located in Iguazú National Park in the Province of Misiones, Argentina (25 $31^{\prime}-25^{\circ}$ $43^{\prime} \mathrm{S}$; $\left.54^{\circ} 08^{\prime}-54^{\circ} 32^{\prime} \mathrm{W}\right)$. The climate is temperatesubtropical and rainy, with no dry season. The annual mean precipitation is $1784 \mathrm{~mm}$ with precipitation peaks in October and May (approx. $200 \mathrm{~mm}$ ) and minimum in March (approx. $100 \mathrm{~mm}$ ). Monthly mean temperatures vary between $31^{\circ} \mathrm{C}$ and $10^{\circ} \mathrm{C}$. The mean annual evapotranspiration is 1050 $\mathrm{mm}$, with evapotranspiration peak in January (Montanelli 2001).

Sampling was carried out in a shallow semipermanent pond, known locally as Laguna Viejo Aeroparque (maximum area: 15,000 $\mathrm{m}^{2}$ ). This pond was selected because it is an important breeding site in the Iguazú National Park for several anuran species. It semi-permanent condition allowed taking samples in two different times: maximum and minimum rainfall. Rooted emergent vegetation was composed of short grasses and bushes, and decaying plant material accumulated on the bottom. The maximum pond depth recorded during the period of heaviest rainfall was $500 \mathrm{~mm}$, and the minimum depth ranged from 20 to $50 \mathrm{~mm}$. Tadpole samples were taken when the pond was completely filled with water (October 1989 and February 1990), and 
when the pond was almost dry (January 1990). Five species of anuran tadpoles co-occurred in Laguna Viejo Aeropuerto. A total 37 tadpoles were collected: Elachistocleis bicolor (Valenciennes, 1832), $\mathrm{n}=6$; Chaunus schneideri (Werner 1894) n=9; Odontophrynus americanus (Duméril and Bibron, 1841), $\mathrm{n}=8$; Scinax granulatus (Peters, 1871), $\mathrm{n}=7$; and Scinax fuscovarius (Lutz 1925), $\mathrm{n}=7$. The tadpoles were identified based on by previous descriptions (Cei 1980, Echeverría 1996), and personal observations (two tadpoles of each species were kept until metamorphosis took place). Taxonomic terminology follows Frost et al. (2006).

Scinax fuscovarius tadpoles were found in October and January, those of $S$. granulatus in February, and those of the remaining species only in October. Gosner's developmental stages ranged from 31 to 38, except for Scinax fuscovarius (stage 25) in October. Tadpoles were fixedin toto in $10 \%$ neutral formalin and staged according to Gosner (1960). Gosner's developmental stages ranged from 31 to 38 , except for Scinax fuscovarius (stage 25) in October.

Based on morphology and field observations tadpoles were grouped into the following three ecomorphological types: E. bicolor (obligate suspension feeder), C. schneideri and $O$. americanus (benthic), and $S$. granulatus and $S$. fuscovarius (nektonic), according to the classifications of exotrophic larvae described by Altig \& Johnston's (1989) and McDiarmid \& Altig (1999).

Guts were completely removed and the contents of the anterior and mid-portions were analysed. Gut contents analyses were based on about $10 \%$ of total of the contents of both gut portions. The food items were identified and quantified using a $40 \mathrm{x}$ objective microscope with a micrometric ocular. We counted several microscope fields per individual until reaching a constant frequency for each item. We used the identification keys of Cyanobacteria, Heterokontophyta (diatoms) and Chlorophyta proposed by Velez \& Maidana (1995), and followed the taxonomy suggested by Anagnostidis \& Komárek (1988), Van Den Hoek et al. (1995) and Komárek \& Anagnostidis (1999). Undamaged algae were counted and their maximum length was measured in $\mu \mathrm{m}$. All other items were classified as animal remains (fragments of arthropods), plant debris (fibers of vascular plants from unidentified species, and damaged but recognizable fibers of Spirogyra sp.), and sediments. The amount of each trophic item was expressed as a percentage of the total gut content per tadpole. The animal remains were quantified individually when its fragmentation prevented the specific identification. Some prey taxa acting as indicators of microhabitat use were used to relate tadpole ecotype to diet. The ecotypes of algae were assigned according to Bourrelly (1970, 1972, 1981), and De Wolf (1982).

Frequency values were calculated for February and October, when the pond was completely filled with water. In the case of S. fuscovarius, food items of October and January were compared. Comparisons between frequencies of planktonic and benthic items in tadpole gut contents per species were analyzed using the Chi-square test $\left(x^{2}\right)$, if there was feeding items predominance.

\section{RESULTS}

The diet compositions among individual tadpoles of the same species do not showed extreme variations.

The gut contents of E. bicolor were exclusively composed of diatoms and chlorophytes, and lacked sediments and animal remains (Table I). Melosira varians, Closterium gracile and Ulothrix sp., which are planktonic algae were the most frequent, and accounted for $92 \%$ of the taxa identified. The remaining $8 \%$ were algae with varied habits (Table II). Most particles were $\leq$ 25-50 $\mu \mathrm{m}$ (Table III).

The trophic spectrum of the benthic and nektonic tadpoles was comprised of animal remains, plant debris, diatoms and sediments (Table I). Plant debris was abundant in $O$. americanus, $S$. granulatus and $S$. fuscovarius. Sediments were absent in $S$. granulatus, and were abundant in $C$. schneideri and S. fuscovarius. Chaunus schneideri showed the highest percentage of sediments in October. Scinaxfuscovarius doubled its percentage of sediments in January. There were a low proportion of algae in the gut contents of benthic and nektonic tadpoles (Table I).

Diatoms represented less than $1 \%$ of the total gut 
Diet of tadpoles of Iguazú National Park: ECHEverRía, D. ET AL.

TABLE I. Mean frequency (\%) of the total items recorded in tadpole gut contents from Laguna Viejo Aeroparque Iguazú National Park, Argentina, (scarce : $\leq 1 \%$ ). I: fibres, II: Spirogyra sp. pieces, III: Cyanobacteria and Chlorophyta, IV: Heterokontophyta (diatoms).

Tabla I. Frecuencia media (\%) del total de items registrados en el contenido intestinal de larvas de la Laguna Viejo Aeroparque Parque Nacional Iguazú, Argentina, (escaso: $\leq 1 \%$ ). I: fibras, II: fragmentos de Spirogyra sp., III: Cyanobacteria and Chlorophyta, IV: Heterokontophyta (diatomeas).

\begin{tabular}{|c|c|c|c|c|c|c|c|c|}
\hline \multirow[t]{2}{*}{ Species } & \multirow[t]{2}{*}{ Date } & \multirow[t]{2}{*}{$\mathrm{n}$} & \multirow{2}{*}{$\begin{array}{c}\text { Animal } \\
\text { rest } \\
(\%)\end{array}$} & \multirow{2}{*}{$\begin{array}{c}\text { Plant } \\
\text { debris } \\
(\%) \\
\mathrm{I}\end{array}$} & \multicolumn{3}{|c|}{$\begin{array}{c}\text { Algae } \\
(\%)\end{array}$} & \multirow[t]{2}{*}{$\begin{array}{c}\text { Sediments } \\
(\%)\end{array}$} \\
\hline & & & & & II & III & IV & \\
\hline Elachistocleis bicolor & Oct & 6 & - & - & - & 43 & 57 & - \\
\hline Chaunus schneideri & Oct & 9 & 1 & 33 & 11 & scarce & Scarce & 55 \\
\hline Odontophrynus americanus & Oct & 8 & 7.8 & 61 & 11.5 & 2 & Scarce & 17.5 \\
\hline Scinax granulatus & Feb & 7 & 11 & 68 & 13.5 & 4.30 & 3.20 & - \\
\hline \multirow[t]{2}{*}{ Scinax fuscovarius } & Oct & 4 & 23 & 49 & - & 1 & 2 & 25 \\
\hline & Jan & 3 & 5 & 35 & 7 & 1 & 2 & 50 \\
\hline
\end{tabular}

TABLE II. Mean frequency (\%) of algae recorded in the guts of tadpoles from Laguna Viejo Aeroparque Iguazú National Park, Argentina, and ecotype of each algae taxon recorded in the gut contents. Abbreviations: E: epiphytic; P: planktonic, $\mathrm{V}$ : variable habits.

TABLA II. Frecuencia media (\%) de algas registradas en el contenido intestinal de larvas de la Laguna Viejo Aeroparque Parque Nacional Iguazú, Argentina, y ecotipo de cada taxón de alga registrado en el contenido intestinal. Abreviaturas: E: epifítica; P: planctónica, V: hábitat variable.

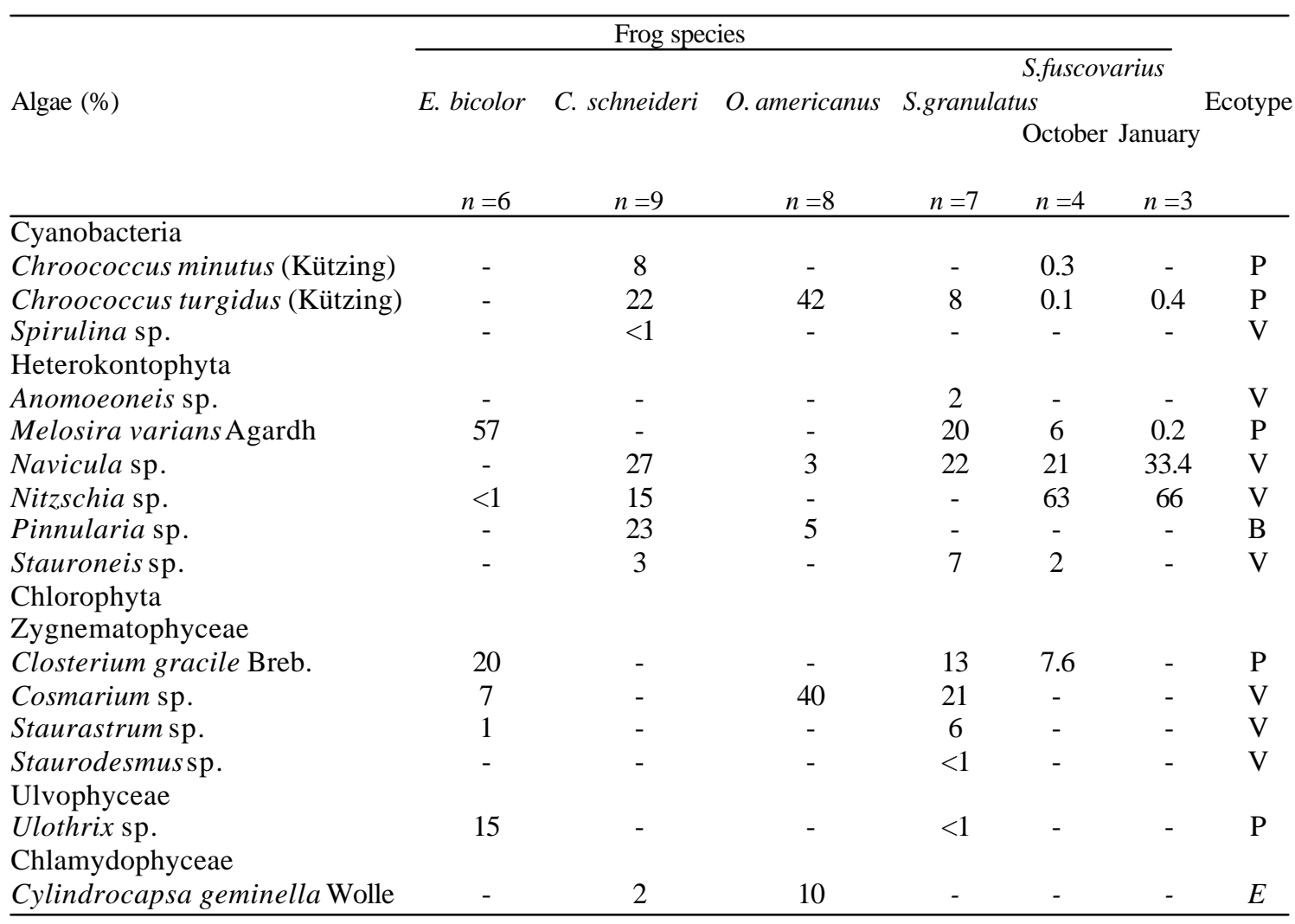


Gayana 71(1), 2007

contents of benthic tadpoles (Table I). In $C$. schneideri, diatoms (Navicula sp., Pinnularia sp. and two species of Chroococcus), accounted for $80 \%$ of the total algal items (Table II). The diatoms Navicula sp. and Nitzschia sp. were the largest particles $(\geq 100 \mu \mathrm{m})$ identified, others showed a wide range of sizes (Table III).

In O. americanus, Chroococcus turgidus and Cosmarium sp. were the most abundant items accounting for $82 \%$ of algae found. Their particle size was $\leq 25 \mu \mathrm{m}$ (Table II, III).

In S. granulatus, Navicula sp., Melosira varians, Cosmarium sp. and Closterium gracile accounted for $76 \%$ of algae. Four planktonic algae,
Chroococcus turgidus (8\%), Closterium gracile (13\%), Melosira varians $(20 \%)$ and Ulothrix sp. $(<1 \%)$, were found in different proportions. Their particle sizes varied from $\leq 25-100 \mu \mathrm{m}$ (Table II, III). In February (low precipitation), high amounts of animal rest and plant debris were found, without sediments in $S$. granulatus.

In October, the gut content of $S$. fuscovarius presented high proportion (84\%) of Navicula sp. and Nitzschia. Melosira varians and Closterium gracile, which are planktonic algae, were also present. Their particle sizes varied from $\leq 25$ to $100 \mu \mathrm{m}$ (Table II, III).

The comparison between the frequencies of

TABLE III. Mean frequency (\%) of algae of size classes in the guts of tadpoles from Laguna Viejo Aeroparque, Iguazú National Park, Argentina.

TABLA III. Frecuencia media (\%) de algas por clase de tamaño en el contenido intestinal de larvas de la Laguna Viejo Aeroparque Parque Nacional Iguazú, Argentina.

\begin{tabular}{|c|c|c|c|c|c|c|c|c|c|c|c|c|c|c|c|c|}
\hline \multirow[b]{3}{*}{ Algae } & \multicolumn{14}{|c|}{ Particle Size Classes } & & \\
\hline & \multicolumn{5}{|c|}{$\leq 25 \mu \mathrm{m}$} & \multicolumn{5}{|c|}{$26-50 \mu \mathrm{m}$} & \multicolumn{4}{|c|}{$51-100 \mu \mathrm{m}$} & \multicolumn{2}{|c|}{$>100 \mu \mathrm{m}$} \\
\hline & 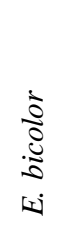 & 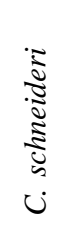 & 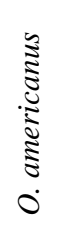 & 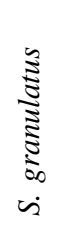 & 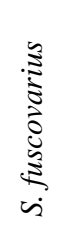 & 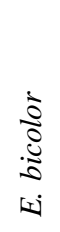 & 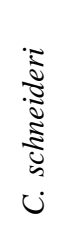 & 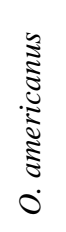 & 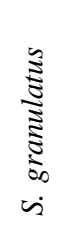 & 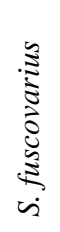 & 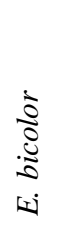 & 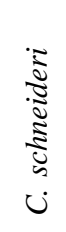 & 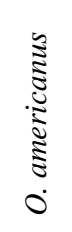 & 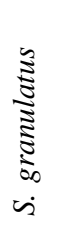 & 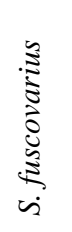 & 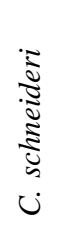 \\
\hline Chroococcus minutus & - & 100 & - & - & 100 & - & - & - & - & - & - & - & - & - & - & - \\
\hline Chroococcus turgidus & - & 100 & 80 & 100 & 100 & - & - & 20 & - & - & - & - & - & - & - & - \\
\hline Anomoeoneis sp. & - & - & - & - & - & - & - & - & 100 & - & - & - & - & - & - & - \\
\hline Melosira varians & 78 & - & - & 43 & - & 22 & - & - & 43 & 77 & - & - & - & 14 & 23 & - \\
\hline Navicula sp. & - & 3 & 17 & 1 & 14 & - & 68 & 83 & 81 & 72 & - & 19 & - & 18 & 14 & 10 \\
\hline Nitzschia sp. & 80 & - & - & - & 77 & 20 & 85 & - & - & 23 & - & 5 & - & - & - & 10 \\
\hline Pinnularia sp. & - & - & - & - & - & - & 100 & - & - & - & - & - & 100 & - & - & - \\
\hline Stauroneis sp. & - & - & - & - & 100 & - & 100 & - & 6 & - & - & - & - & 94 & - & - \\
\hline Closterium gracile & 75 & - & - & 97 & - & 25 & - & - & 3 & 81 & - & - & - & - & 19 & - \\
\hline Cosmarium sp. & 33 & - & 58 & 83 & - & 67 & - & 40 & 15 & - & - & - & - & 2 & - & - \\
\hline Staurastrum sp. & 100 & - & - & 10 & - & - & - & - & 35 & - & - & - & - & 55 & - & - \\
\hline Ulothrix sp. & 16 & - & - & 100 & - & 68 & - & - & - & - & 16 & - & - & - & - & - \\
\hline Cylindrocapsa geminella & - & 33 & - & - & - & - & 67 & - & - & - & - & - & - & - & - & - \\
\hline Other green algae & - & - & 30 & - & - & - & - & 13 & - & - & - & - & 57 & - & - & - \\
\hline
\end{tabular}


planktonic components (C. minutus, C. turgidus, $M$. varians, $C$. gracile and Ulothrix sp.) and benthic components (sediments) present in the tadpole intestines, shows no significant differences in $C$. schneideri $\left(X_{0.05 ; 1}^{2}=3.69, \mathrm{P}<0.054\right)$. In $O$. americanus and $S$. fuscovarius the proportion of planktonic components was significantly higher than that of benthic components in October $\left(X^{2}{ }_{0.05: 1}=\right.$ $11.41, \quad \mathrm{P}<0.001 ; \quad\left(X_{0.05: 1}^{2}=11.2, \quad \mathrm{P}<0.001\right)$ respectively. In January (low precipitation), S. fuscovarius showed scarce planktonic components $(0.6 \%)$ according to the decrease of water level and an increment in sediment frequency (Table I, II).

\section{DISCUSSION}

Our results indicate that the tadpoles of five species coexisting in Laguna Viejo Aeroparque (Misiones, Argentina) are mainly phytophagous, but most showed substantial amounts of sediment in their guts.

The proportion of planktonic algae and sediments varied among species. Elachistocleis bicolor and $S$. granulatus only showed planktonic organisms. In October and February, when the pond was completely water-filled, the absence of sediments in the gut contents in these tadpoles may indicate that they frequently feed in the water column, displaying nektonic behaviour. The feeding place of $S$. granulatus is associated to vegetated area of the waterbody; this explains the absence of sediments and the high frequency of plants and animal rest in its gut content.

The sediment proportion recorded in the gut contents of $S$. fuscovarius specimens varied with changes in the water level of the pond. This result supports the great microhabitat versatility of $S$. fuscovarius, which may alter its feeding in response to changes in the environments. In this species, sediments represented $25 \%$ of the total gut content of tadpoles collected when the pond was water-filled (October) and $50 \%$ of the total gut content when the pond was almost empty (January). The tadpoles collected in January may have been compelled to feed on the bottom due to the low water level of the pond (generated for the high evapotranspiration). Such a plastic response would be impossible to accomplish for obligate suspension feeders.

The sediment content varied between the two species with benthic behaviour, O. americanus and C. schneideri. The latter species showed a higher tendency to feed on the bottom than $O$. americanus. Gallardo $(1963,1974)$ observed that $O$. americanus larvae have a tendency to feed on carrion, particularly dead tadpoles, and swim up to the water surface to breath. The occurrence of $C$. turgidus in the gut content of $O$. americanus and $C$. schneideri may be evidence of vertical movements and therefore, they should be regarded as opportunistic rather than nektonic species.

In spite of the high diversity of prey items recorded in the gut content of tadpoles, only a few of them can be used as indicators of microhabitat use. The pond conditions in October allowed these tadpoles to select the feeding microhabitat, without being forced by low water levels to feed on the bottom. This fact seems to be confirmed by the finding of a high proportion of sediments and vegetable fibers in the gut contents of these anuran species. Even when the pond was totally filled, C. schneideri showed the highest percentage of sediments. Such vegetable fibers may have come from the bottom of the pond.

The gut contents of Elachistocleis bicolor were mostly composed of planktonic algae (Melosira varians, Closterium gracile and Ulothrix sp.) This species shows the typical nektonic behaviour, since they feed almost exclusively in the water column (Echeverría \& Conforti 2000).

The presence of Closterium turgidus has been reported in the gut contents of nektonic tadpoles of Phyllomedusa tetraploidea, a suspension-rasper (sensu Altig \& Johnston 1989), (Lajmanovich \& Faivovich 1998). This finding, together with our results, may represent another link between algal indicators and tadpole ecomorphological types.

Although the sample size is small, our results showed the feeding preference in the water body of the larvae. Besides, E. bicolor is an oral suction feeder, having no keratinized mouth parts, while the rest of the studied species use mainly horny teeth for feeding (Echeverría \& Montanelli 1992, 1995, Echeverría 1996, 1998, Echeverría \& Lavilla 2000). The great variation in the oral morphology of tadpoles, together with the wide spectrum of prey items and particle sizes available in the pond may explain the diversity of food recorded in the gut content of tadpoles in this study. 


\section{ACKNOWLEDGMENTS}

We acknowledge the assistance of Silvana Montanelli in field sampling in agreement with the proceeding of National Parks Administration, and Alicia Vinocur (Limnology Laboratory, FCEN UBA) for its valuable assistance in algae taxonomic identification. We also thank two anonymous reviewers for the suggestions.

\section{BIBLIOGRAPHY}

Altig, R. \& G. F. Johnston 1989. Guilds of anuran larvae: relationships among developmental modes, morphologies and habitats. Herpetological Monograph 3:81-109.

Anagnostidis, K \& J. KomÁrek 1988. Modern approach to the classification system of Cyanophytes. 3 . Oscillatoriales. Arch für Hydrobiologie Suppl 80 Algological Studies 50:327-472.

Bourrelly, P. 1970. Les algues d'eau douce. Initiation à la systématique. Les algues bleues et rouges. Les Eugléniens, Piridiniens et Cryptomonodines. Editions N. Boubée et Cia. 3:1-512.

Bourrelly, P. 1972. Les algues d'eau douce. Initiation à la systématique. Les algues vertes. Editions N. Boubée et Cia 1: 1-572.

Bourrelly, P. 1981. Les algues d'eau douce. Initiation à la systématique. Les algues jaunes et brunes. Chrysophycées, Pteroohycées, Xanthophycées et Diatomées. Societé Nouvelle des Editions Boubée 2:1- 517.

Cei, J.M. 1980. Amphibians of Argentina. Monitore zoologico italiano 2:1-609.

Costa, H.H. \& S. Bramanian. 1965. The food of the tadpoles of Rhacophorus crucifer crucifer (Blyth). Ceylon Journal Science 5:107-109.

De Wolf, H. 1982. Method of coding of ecological data from diatoms for computer utilization. Meded Rijks Geologische Dienst 36:95-98.

Dickman, M. 1968. The effects of grazing by tadpoles on the structure of a periphyton community. Ecology 49: 1188-1190.

EcheverRía, D.D. 1996. Microscopía electrónica de barrido del aparato bucal y de la cavidad oral de "Hyla strigilata eringiophila Gallardo, 1961", (Anura, Hylidae) con comentarios que facilitan su identificación durante la metamorfosis y postmetamorfosis. Physis 54:1-6.

Echeverría, D.D. 1998. Microanatomía de la cavidad bucofaríngea de la larva de tres bufónidos de la Argentina, con comentarios acerca del aparato bucal y del contenido intestinal. Cuadernos de Herpetología 12:1-11.

Echeverría, D.D. \& V. Conforti. 2000. Euglenoids living in the intestines of microhylid tadpoles of Argentina. Alytes 18:81-89.
Echeverría, D.D. \& E.O. LaVilla. 2000. Internal oral morphology of tadpoles of Dermatonotus muelleri and Elachistocleis bicolor. Journal of Herpetology 34:517-523.

Echeverría, D.D. \& S.B. Montanelli. 1992. Estereomorfología del aparato bucal y cavidad oral de las larvas de Ololygon fuscovaria (Lutz, 1925) (Anura, Hylidae). Revista del Museo Argentino de Ciencias Naturales "Bernardino Rivadavia" 16: 3-13.

Echeverría, D.D. \& S.B. Montanelli. 1995. Acerca del aparato bucal y de las fórmulas dentarias de Odontophrynus americanus (Duméril y Bibron, 1841) (Anura, Leptodactylidae). Physis 50:37-43.

Farlowe, V. 1928. Algae of ponds as determined by an examination of the intestinal contents of tadpoles. Biological of Bulletin 35:443-448.

Frost, D. R., T. Grant, J. Faivovich, R. H. B ain, A. Haas, C. F. B. Haddad, R. O. De Sá ,A. Channing, M. Wilkinson, S. C. Donnellan, C. J. Raxworthy, J. A. Campbell, B. L. B lotto, P. Moler, R. C. Drewes, R. A. Nussbaum, J. D. Lynch, D. M. Green, \& W. C. Wheeler. 2006. Amphibian tree of life. Bulletin of The American Museum of Natural History 297:1-371.

Gallardo, J.M. 1963. Observaciones biológicas sobre Odontophrynus americanus (Duméril y Bibron, 1841). Ciencia e Investigación 19:177-186.

Gallardo, J.M. 1974. Anfibios de los alrededores de Buenos Aires. Buenos Aires Eudeba 1-231 pp.

Gallardo, J.M. \& E. Varela de Olmedo. 1992. Amphibia. Fauna de agua dulce 41:1-116.

Gosner, K.L. 1960. A simplified table for staging anuran embryos and larvae with notes on identification. Herpetologica 16: 183-190.

Heyer, W.R. 1973. Ecological interactions of frog larvae at a seasonal tropical location in Thailand. Journal of Herpetology 7:337-361.

Heyer, W.R. 1976. Studies in larval amphibian habitat partitioning. Smithson Contribution Zoology 242:1-27.

Hoff, K., A. Blaustein, R.W. McDiarmid \& R. Altig. 1999. Behavior. Interactions and their Consequences. 215-239. In: McDiarmid RW \& Altig R (eds), Tadpoles. The biology of anuran larvae. University Chicago Press, London.

INGER, R.F. 1986. Diets of tadpoles living in a Bornean rain forest. Alytes 5:153-164.

I ZAGuirRe, I., M. Boveda \& G. Tell.1986. Dinámica del fitoplancton y características limnológicas en dos estanques de la ciudad de Buenos Aires. Physis 44:25-38.

KomáreK, J. \& K. Anagnostidis. 1999. Cyanoprokaryota . Teil: Chroococcales. Gustav Fischer, Jena, Stuttgart Lübeck Ullm 1:1-548.

Kupperberg , S.J. 1997a. The role of diet in anuran metamorphosis. American Zoology 37:146-159.

KuPPERBERG, S.J. 1997b. Bullfrog (Rana catesbeiana) invasion of a California river: the role of larval competition. Ecology 78: 1736-1751. 
Diet of tadpoles of Iguazú National Park: EcheverRía, D. ET AL

Ku PFERBERG, S.J. 1997c. Facilitation of periphyton production by tadpole grazing: functional differences between species. Freshwater Biology 37:427-437

Kupferberg, S.J., J.C. Marks \& M.E. Power. 1994. Effects of variation in natural algal and detrital diets on larval anuran (Hyla regilla) life history traits. Copeia: 446-457.

Lajmanovich, R.C. 1994. Contribución al conocimiento de la alimentación de larvas de la rana crio1la Leptodactylus ocellatus (Amphibia, Leptodactylidae) en el Paraná medio, Argentina. Studies on Neotropical Fauna Environmental 29: 55-61.

Lajmanovich, R.C. \& J. Faivovich . 1998. Dieta larval de Phyllomedusa tetraploidea Pombal \& Haddad, 1992 en la provincia de Misiones (Argentina). Alytes 15:137-144.

McDiarmid, R.W. \& R. Altig. 1999. Tadpoles. The biology of anuran larvae. University of Chicago Press. 1- 444 pp.

Montanelli, S.B. 2001. Notas sobre ecología alimentaria, densidad relativa e impacto turístico en los carnívoros del Parque Nacional Iguazú, Misiones Argentina. Doctoral Thesis, FCEyN, Universidad de Buenos Aires:1-159.

Sanderson, S.L. \& S.J. Kupferberg. 1999. Development and evolution of aquatic larval feeding mechanisms:301-377. In: Hall B.R. \& MH Wake (eds). The origin and evolution of larval forms. 1-425. London Academic Press.

SAvAGE, R.M. 1952. Ecological, physiological and anatomical observations on some species of anuran tadpoles. Proceeding of the Zoological Society of London 122:467-514.

Skelly, D.K. 1995. Competition and the distribution of the spring peeper larvae. Oecologica 103:203-207.

Smith, D.C. \& J. VAN Buskirk. 1995. Phenotypic design, plasticity, and ecological performance in two tadpole species. American Naturalist 145:211-233.

Van Den Hoek, C., D.G. M onn \& H. M. Jahns. 1995. Algae. An introduction to phycology. Cambridge University Press: 1-623.

Vélez, C.G. \& N. Maidana. 1995. Algae. In: Lopretto EC, Tell G, eds. Ecosistemas de Aguas Continentales: Metodologías para su estudio. 2. 379442. La Plata, Ediciones Sur.

Viertel, B. 1990. Suspension feeding of anuran larvae at low concentrations of Chlorella algae (Amphibia, Anura). Oecologia 85:167-177.

Viertel, B. 1992. Functional response of suspension feeding anuran larvae to different particle sizes at low concentrations (Amphibia). Hydrobiologia 234:151-173.

Waringer-Loschenkohl, A. 1988. An experimental study of microhabitat selection and microhabitat shifts in European tadpoles. Amphibia-Reptilia 9:219-236.

Werner, E.E. 1986. Amphibian metamorphosis: Growth rate, predation risk, and the optimal size at transformation. American Naturalist 128:319-341. 